\title{
RECREATIONAL BOAT FISHING PRESSURE ON FISH COMMUNITIES OF THE SHELF AND SHELF BREAK OF FAIAL AND PICO ISLANDS (AZORES ARCHIPELAGO): IMPLICATIONS FOR COASTAL RESOURCE MANAGEMENT
}

\author{
Hugo DIOGO* and João G. PEREIRA
}

Departamento Oceanografia e Pescas, Universidade dos Açores, Horta, Portugal

\begin{abstract}
Diogo H., Pereira J.G. 2013. Recreational boat fishing pressure on fish communities of the shelf and shelf break of Faial and Pico Islands (Azores Archipelago): implications for coastal resource management. Acta Ichthyol. Piscat. 43 (4): 267-276.
\end{abstract}

\begin{abstract}
Background. Several studies have highlighted the negative potential of recreational boat fishing to put pressure on coastal fish species and in particular on those that are vulnerable. We focused on this problem launching the first such survey in the area on this type of fishery in the Azorean region. We were trying to assess the catch, harvest, and effort, to investigate spatial and temporal variability, compared with commercial artisanal harvesting, and to evaluate ecological implications of this activity.

Materials and methods. Recreational boat fishing was surveyed at the islands of Faial and Pico during 2004 and 2005 to assess the level of pressure on fish communities. Eighty-seven anglers representing 46 boats were interviewed. The questionnaires covered fishing data (fishing technique, gear, fishing effort, and spatial distribution), socio-economic information, and biological sampling (species identification and measurements).

Results. The anglers from the recreational boats surveyed employed four different fishing techniques, however, the demersal fishing was undoubtedly the most common (87.5\%). The activity took place around the islands with no activity at neighbouring offshore fishing grounds. A total of 32 fish species were identified in the demersal fishing catch. The estimated catches reached $163 \mathrm{t}$ per year $(39.7 \%$ of the commercial artisanal captures). The weighted mean trophic level and vulnerability index values from the demersal fishing catch corresponded to 3.8 and 45.3 , respectively.

Conclusion. The impact of the demersal recreational fishing on the fish communities of the shelf and upper slope of the islands studied is substantial, affecting a number vulnerable fish species (e.g., Epinephelus marginatus, Polyprion americanus, and Scorpaena scrofa). The recreational fisheries in the area is also a major competitor for the same resources as the commercial artisanal fishermen, since $75 \%$ of the species composition captured by recreational boat anglers is simultaneously landed by commercial artisanal fisheries. A monitoring program covering the recreational fisheries is urgently needed to improve the current management strategy in the coastal areas of the Azorean Archipelago.
\end{abstract}

Keywords: recreational fishing, trophic levels, fish vulnerability, coastal fisheries management

\section{INTRODUCTION}

Recreational fishing is one of the most popular leisure activities in coastal areas of the world, involving large numbers of participants and consequently responsible for high levels of fishing effort (Cowx 2002, McPhee et al. 2002, Pitcher and Hollingworth 2002).

Scientific research on recreational fishing in recent decades has experienced worldwide growth bringing to light evidence of the negative impacts of this sector on marine coastal areas, which are similar to those known for commercial fisheries. The consequences of recreational fishing usually go far beyond direct impacts on the exploited species to those that occur on marine ecosystems (e.g., truncation of the natural age and size structure, trophic changes, loss of genetic variability and evolutionary changes) (McPhee et al. 2002, Coleman et al. 2004, Cooke and Cowx 2004, Cooke et al. 2006). Despite this known fact, few countries have based their fisheries management policies on both recreational and commercial fishing data. Fishery managers are just beginning to fully understand the importance of integrating information for both sectors. In part, this change of perspective was related with the increasing awareness of the global overfishing process (Cooke and Cowx 2004).

A transition from subsistence fishing to recreational fishing has been seen in many areas of the world (e.g., Mediterranean Sea) and was due in large part to economic development and led to several structural changes in the

\footnotetext{
${ }^{*}$ Correspondence: Dr Hugo Diogo, Departamento Oceanografia e Pescas (DOP), Universidade dos Açores, Rua Professor Doutor Frederico Machado, $9901-862$ Horta,
} Portugal, phone: (+351) 292200 400, fax: (+351) 292200 411, e-mail: hugodiogo@uac.pt. 
society (Morales-Nin et al. 2005). Nowadays, boat fishing is one of the most important recreational fishing activities in the world and can have great economic importance. However, evidence suggests that it exerts pressure on coastal fish communities (Morales-Nin et al. 2005, Lloret et al. 2008b), and several countries have implemented long-term survey programs in order to monitor the saltwater fish stocks in the face of recreational fishing (Coleman et al. 2004, Wise et al. 2012).

In Portugal, recreational fishing experiences an increasing popularity and with recognized socioeconomic importance (Marta et al. 2001). In the Azores this activity is also viewed as a tradition with roots that go back to the colonization of the islands. The previous subsistence mode of coastal fishing, existent during earlier periods of colonization, has transformed into a leisure activity, highly appreciated by the local population. Specific regulations to control recreational fishing harvest in the Azores began in 1985 but only for spear fishing with bag limits and licenses. Until recently recreational boat fishing was only managed through restrictions for minimum catch size for some species. However, in 2008, new specific regulations for recreational boat fishing were enforced and current limitations in the Azores included daily bag limits, gear limitations, and fishing licenses.

While the Azorean spear fishing has been previously studied (Diogo and Pereira 2013), the boat fishing remains poorly investigated. This survey for recreational boat fishing on the islands of Faial and Pico represents the first initiative to collect information about this type of fishery in the region, to assess catch, harvest, and effort, to investigate spatial and temporal variability, to make comparisons with commercial harvesting, and to evaluate the ecological implications of this activity.

\section{MATERIALS AND METHODS}

Study site. This study was carried out on the islands of Faial and Pico in the Azores Archipelago. The Azores consists of nine volcanic islands that are part of the MidAtlantic Ridge. Due to the recent origin of the Azorean Archipelago the islands present narrow shelves and steep slopes. The Azorean shelf break-natural boundary between the physiographic provinces of island shelf and slope (Southard and Stanley 1976, Quartau et al. 2010) - limited to $200 \mathrm{~m}$ depth (Menezes et al. 2006) is extremely close to the coastline in comparison to the continental margins. The islands and the contiguous shallow waters $(<500 \mathrm{~m}$ depth $)$ correspond to only $0.4 \%$ of the Exclusive Economic Zone (EEZ) of about one million $\mathrm{km}^{2}$ (Isidro 1996*). The Faial and Pico islands have perimeters of $61.15 \mathrm{~km}$ and 109.50 $\mathrm{km}$ and areas of $173.11 \mathrm{~km}^{2}$ and $447.74 \mathrm{~km}^{2}$, respectively (Guénette and Morato 2001) (see Fig. 1). Faial Island is more densely inhabited and the total population in each island is approximately 15000 people. The main villages in Pico are Madalena, Lajes, and São Roque while in Faial the population is mainly concentrated around the town of Horta (Anonymous 2011a). The islands of Faial and Pico present a high number of areas where vessels can be launched by cranes or boat ramps, or where the boats can be moored or anchored in marinas. On the island of Faial, 11 sites with water access with boat ramps and/or cranes were identified as well as one large marina where a substantial number of resident recreational boats. In Pico there are 24 water-access sites with boat ramps and/or cranes and also two small marinas (Lajes do Pico and Madalena) (Fig. 1).

Data collection. A roving creel survey (on-site angler surveys during which catch composition is examined) (Pollock et al. 1994, Font and Lloret 2011) was conducted by car, from October 2004 to September 2005, with 193 sampling days in total $(48.2 \%$ in Faial; $51.8 \%$ in Pico). The coastline was subdivided into four sections in Faial and five sections in Pico (Fig. 1). In each section, a route (transect) was defined in order to cover all the boat access points to water. The survey was designed (Sigler and Sigler 1990, McGlennon and Kinloch 1997) to collect monthly information at different strata:

- Morning and afternoon (time);

- Weekends and weekdays (day type);

- Different spatial sampling units.

Within each combination of sampling days and units for each island, one sampling unit in the morning and one in the afternoon were previously chosen randomly to be carried out. A random starting time in each combination was selected during sampling and the duration per circuit was approximately $2 \mathrm{~h} 30 \mathrm{~min}$ in Faial and $3 \mathrm{~h} 30 \mathrm{~min}$ in Pico. During the circuit the presence of trailers at boat ramps advertised the presence of boats in the water to the survey team. Usually the team waited for 15-30 min for the angler to return to the point of access. In the case of marinas the waiting time was higher (30-45 min). In general the anglers' response to the interviews was good, with 7 refusals to interview, while 87 anglers representing 46 boats were surveyed which corresponded to about $11 \%$ of the recreational boats in the area (values based on boat license records for 2008; unpublished data from Regional Fisheries Inspection, Azorean Government). The interviews were accomplished at 14 different water access sites with $37 \%$ of the interviews in Faial and $63 \%$ in Pico. Catch and bait data presented here were only for anglers using demersal fishing since the use of others techniques was less common.

Fishing techniques. Four fishing techniques were identified: demersal fishing, jigging for small pelagics, squid jigging, and trolling. The jigging tackle for small pelagics is composed of a fishing line, 4 to 8 small fishing lures covered by feathers, and a small lead sinker at the end of the line. The squid jigging gear usually consists of wire lines, manual haulers, and squid jig lures (in some cases natural bait can be added). The trolling equipment consists of a fishing line that is towed behind the boat at the speed of 2 to 5 knots, depending of the target species and it employs artificial bait (e.g., plastic fish or squid). Demersal fishing practiced by means of a heavy lead sinker at the end of the line and mainly using natural bait to catch fish close to the seabed. This technique can pres-

\footnotetext{
${ }^{*}$ Isidro E.J. 1996. Biology and population dynamics of selected demersal fish species of the Azores Archipelago. PhD thesis, University of Liverpool, Port Erin, Isle of Man, UK. [In English].
} 
ent different methods of cast and retrieve (rod and reel, manual haulers, and manually) and different types of lines (nylon, braided lines, and wire). Shallow demersal anglers usually use nylon or multifilament lines by means of rod and reel or handling. Deeper demersal anglers usually use multifilament lines by means of rod and reel or wire lines wielded by hand or by a manual hauler.

Fishing data. Interviews of the boat owners usually covered the following items: fishing method, fishing gear(s), bait, time spent fishing, and biological sampling which consisted of species identification and size measurement to total length of individuals as well as quantification of the discards. The total weight in the catch was calculated using the length frequencies derived from the measured sizes and the species' length-weight relation described by Morato et al. (2001), Froese and Pauly (2013). The mean catch per unit effort (CPUE) was estimated as the catch $[\mathrm{kg}]$ per angler per hour.

A direct estimation of the total number of recreational fishing boats present in the study area was not possible but was assumed to be equivalent to the number of licenses issued in 2008 (first year of mandatory licenses for recreational boat fishing). The number of recreational boat fishing licenses issued in 2008 in Faial and Pico was of 432. In the following years (2009-2011) the values of licenses issued was similar $(412,411$, and 408, respectively) which corresponded to $31.5 \%$ of the mean number of licenses issued in the same period in the Azorean region (data from Regional Fisheries Inspection; Azorean Government).

The total catch estimated for the study period and area was adapted from procedures of Lloret et al. (2008b). The calculation was divided in three main steps:

- Mean fishing effort of recreational seabed fishing was calculated as, (average number of fishing hours per angler $) \times$ (average number of annual fishing operations per angler $) \times($ average number of anglers per boat);

- Mean annual catch per vessel was, (mean fishing effort per vessel $) \times($ mean CPUE in weight per angler per hour);

- Estimated total catch of recreational seabed fishing for the study area and period was calculated as (number of recreational fishing licenses issued in 2008) $\times($ mean annual catch per vessel).

Food webs largely define ecosystems and the trophic level defines the position of organisms within the food webs (Pauly and Christensen 2000). Trophic levels are based on individual prey items in their diet since food items define predator-prey relation. The trophic level of each fish species was obtained from Froese and Pauly (2013).

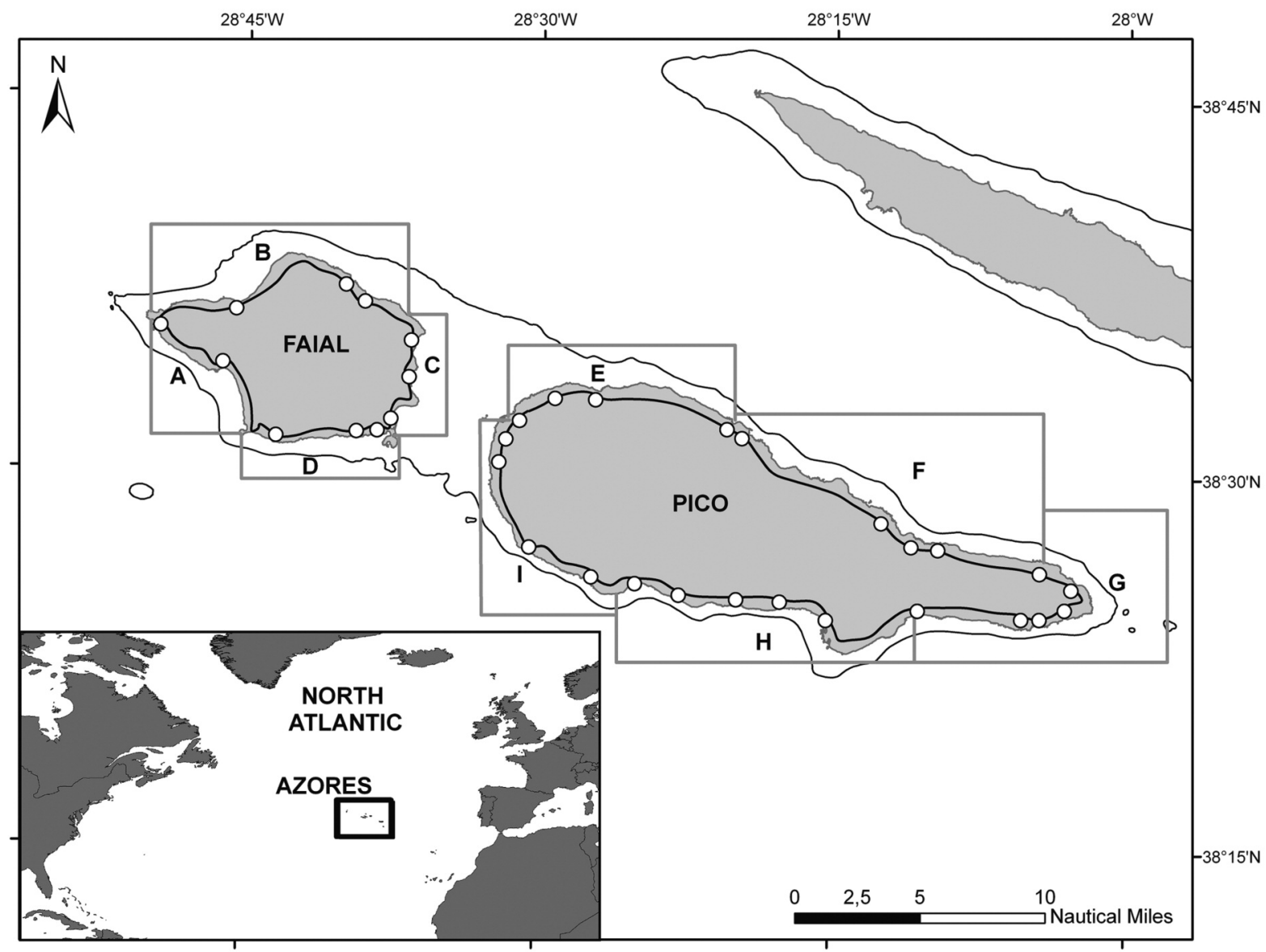

Fig. 1. The islands of Faial and Pico of the Azores Archipelago, North Atlantic (Azores on the inset) showing the spatial units of the roving creel survey targeting catch parameters of recreational fishing boats (A through I; grey lines); Black line marks the $200 \mathrm{~m}$ isobath; White circles point out the location of marinas, cranes, and boat ramps 
The weighted average trophic levels in the demersal boat fishing catches were calculated from the arithmetic mean of the trophic level of all species weighted by their catch (Font and Lloret 2011). In addition, we calculated the index of intrinsic vulnerability that is based on life history of marine fish and its ecological characteristics (Cheung et al. 2005). The index ranges from 1 to 100 , distinguishing four levels of vulnerability: low (1-40), moderate (40-60), high (60-80), and very high (80-100). The intrinsic vulnerability values per species (or intrinsic genus vulnerability when the species information was not available) were obtained from Cheung et al. (2007). This procedure was analogous to that described by Lloret et al. (2008a) being the calculation performed as "the arithmetic mean of the intrinsic vulnerability of fish taxa weighted by their catch". Socio-economic and fishing effort information data. The fishery was conducted exclusively by private boats by anglers resident to the islands where the survey was carried out and the following questions were posed during each interview: gender, age, frequency (fishing days per year), seasonality, fishing areas, fate of the catches (sale or personal consumption), annual fishing expenses.

\section{RESULTS}

Characteristics of the fishing activity. The surveyed boats were mainly open decked (95\%) and were occasion- ally seen to use more than one type of fishing technique (4.7\%). From the four fishing techniques identified the demersal fishing was the most common with $87.5 \%$ of the total anglers surveyed, followed by jigging for small pelagics $(8.7 \%)$, trolling $(2.1 \%)$, and squid jigging $(2.1 \%)$. Demersal anglers mainly used hand-held lines $(76.3 \%)$ but the use of manual haulers was also identified $(21.4 \%$ of fishing operations) as well as rod and reel $(2.3 \%)$. The line material used in $78.6 \%$ of fishing operations surveyed was nylon or multifilament while in $21.4 \%$ wire lines with manual haulers were employed, for deeper fishing.

The spatial distribution of recreational boat fishing activity, as inferred from the interviews, was mainly around the islands with no activity taking place at neighbouring offshore fishing grounds. The most frequently indicated fishing spots were the Faial-Pico channel and the south coast of Faial (Fig. 2).

Crew numbers averaged 1.9 anglers per boat indicating that participants typically go fishing in pairs (52.3\%), but a high number of unaccompanied anglers was also observed $(31.8 \%)$, while crew members with three and four members on board were less frequent $(13.6 \%, 2.3 \%$, respectively). Only seven anglers reported discarded fish, releasing the smallest individuals caught and species of little gastronomic interest-e.g., Atlantic lizardfish, Synodus saurus (Linnaeus, 1758).

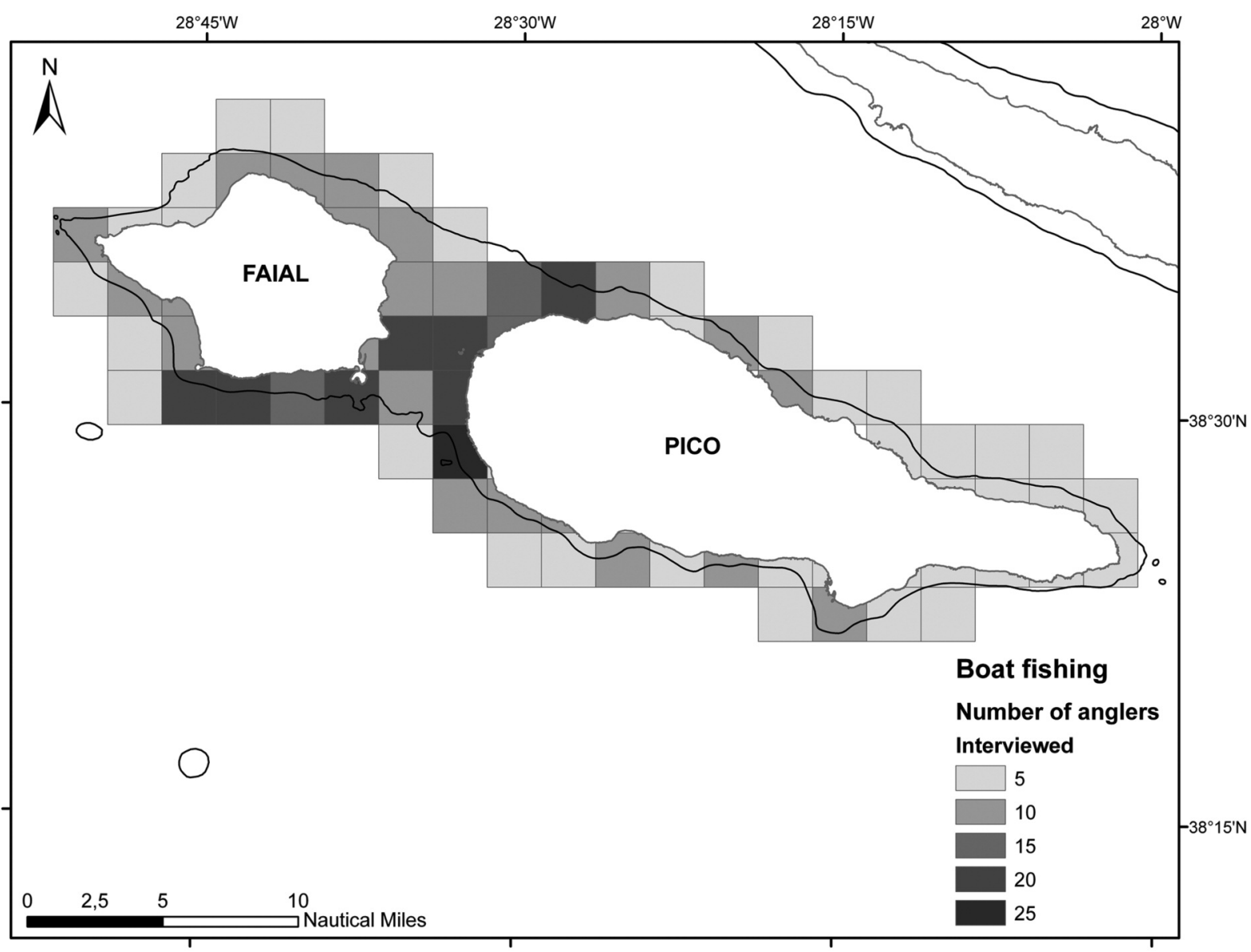

Fig. 2. The number of boat anglers interviewed in individual fishing areas around Faial and Pico islands of the Azores Archipelago, North Atlantic (study area) in the course of the presently reported study; Black line marks the $200 \mathrm{~m}$ isobath 
The majority of the bait used was natural (94.1\%), while $45.1 \%$ of the bait was directly captured by the anglers and the rest bought frozen in local stores. Half of the captured bait was collected by hand in the intertidal zone during low tide, targeting the marbled rock crab, Pachygrapsus marmoratus, while $41.7 \%$ of the bait was captured by angling - e.g., blue jack mackerel, Trachurus picturatus (Bowdich, 1825), Katsuwonus pelamis (Linnaeus, 1758) - and $8.3 \%$ by hand netting-e.g., Euphausiacea and a Myctophidae species, Lepidophanes gaussi (Brauer, 1906) (see Fig. 3).

The level of compliance of boat anglers with recreational fishing regulations was relatively good, but the main problem identified was the anglers' tendency to illegally sell part of their catch (10.3\%). Also the anglers' compliance with regulations for the minimum legal landing size was good (Table 1).

Catch composition. The biological sampling from the overall catch made by all demersal anglers amounted to 32 fish species (Table 1). Demersal species dominated sampling with only nine species being pelagic or benthopelagic. The family Sparidae was the most representative in the catches because 5 of the 33 species belonged to that family. The blacktail comber, Serranus atricauda Günther, 1874, was the most abundant species in the catch, in terms of weight and number $(24.6 \%$ and $45.9 \%$, respectively). The second most represented species in terms of weight and number was the blackspot seabream, Pagellus bogaraveo (Brünnich, 1768) (12.0\%, 12.3\%; respectively). Other species with important catches were the Atlantic chub mackerel, Scomber colias Gmelin, 1789, followed by the Ballan wrasse, Labrus bergylta
Ascanius, 1767 (Table 1). Additionally, 24 species captured by both the commercial and recreational boat fishing were detected.

The weighted mean index of vulnerability in the captured fish was 45.3 (out of 100), however ranging from 28-for grey triggerfish, Balistes capriscus Gmelin, 1789, and Azores chromis, Chromis limbata (Valenciennes, 1833) - to 77-for silver scabbardfish, Lepidopus caudatus (Euphrasen, 1788). The weighted mean trophic level in the catch was 3.8 but it ranged from 2.9-for parrotfish, Sparisoma cretense (Linnaeus, 1758)-to 4.5-for Almaco jack, Seriola rivoliana Valenciennes, 1833, and Atlantic lizardfish, Synodus saurus. The mean lengths of eight captured species were lower than their maturity size: splendid Alfonsino, Beryx splendens Lowe, 1834; European conger, Conger conger (Linnaeus, 1758); silver scabbardfish; wreckfish, Polyprion americanus (Bloch et Schneider, 1801); offshore rockfish, Pontinus kuhlii (Bowdich, 1825); thornback ray, Raja clavata Linnaeus, 1758; Almaco jack, and blue jack mackerel (Table 1). None of the fish captured were below the size limits set by the legislation applicable at that time.

In addition to the species mentioned above in the "Results" the catch list includes also less important fish such as: Pseudocaranx dentex (Bloch et Schneider, 1801); Phycis phycis (Linnaeus, 1766); Centrolabrus caeruleus Azevedo, 1999; Coris julis (Linnaeus, 1758); Muraena augusti (Kaup, 1856); Muraena helena Linnaeus, 1758; Boops boops (Linnaeus, 1758); Diplodus sargus (Linnaeus, 1758); Pagellus acarne (Risso, 1827) (Table 1).

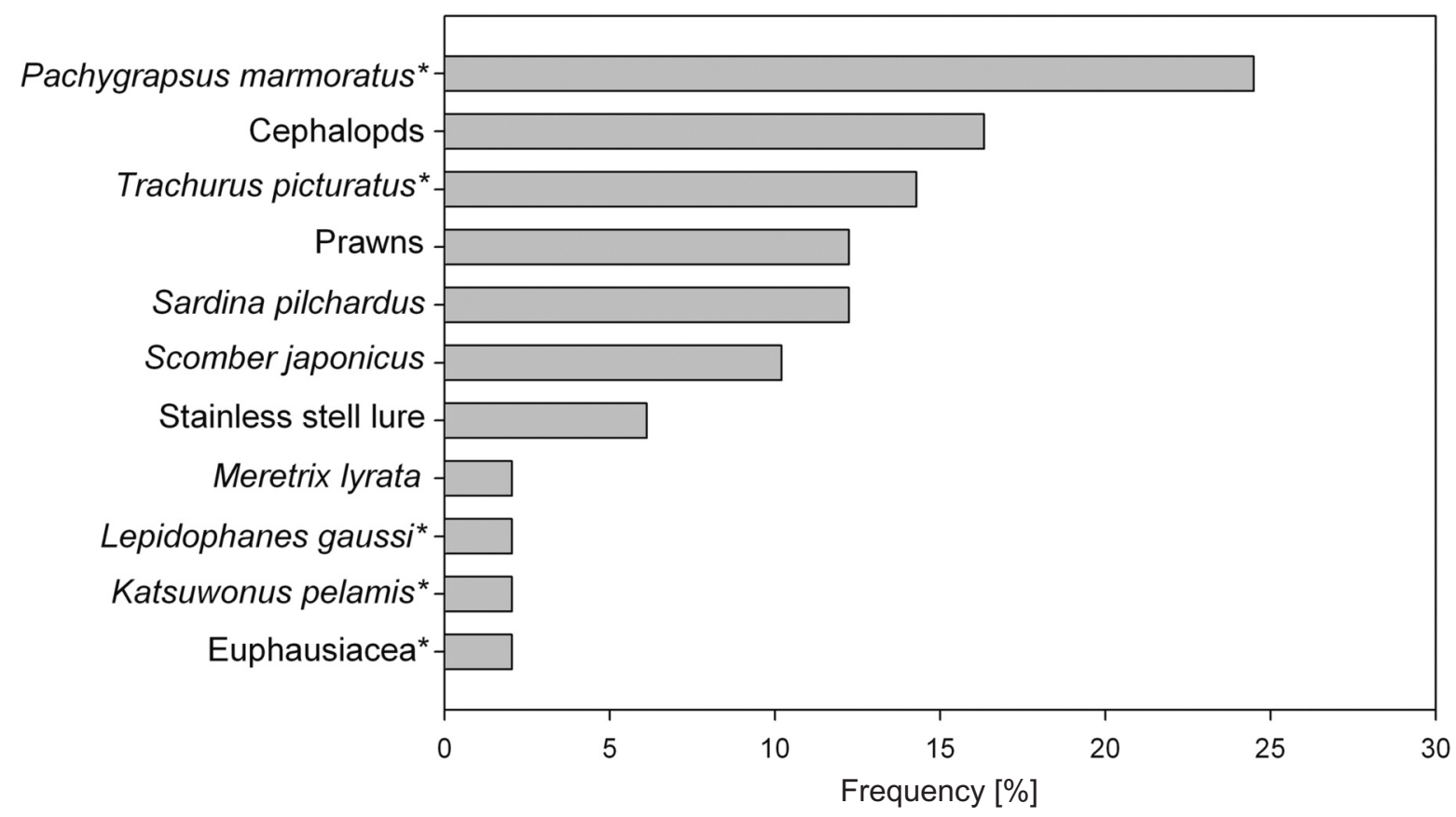

Fig. 3. Baits used by boat anglers interviewed during the survey carried out around Faial and Pico islands of the Azores Archipelago, North Atlantic; The asterisk marks the baits captured by the angler, as opposed to the purchased baits (Pachygrapsus marmoratus is a crab, while Meretrix lyrata is a clam) 
흘

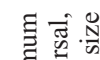

罗

II 11 :

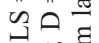

宇

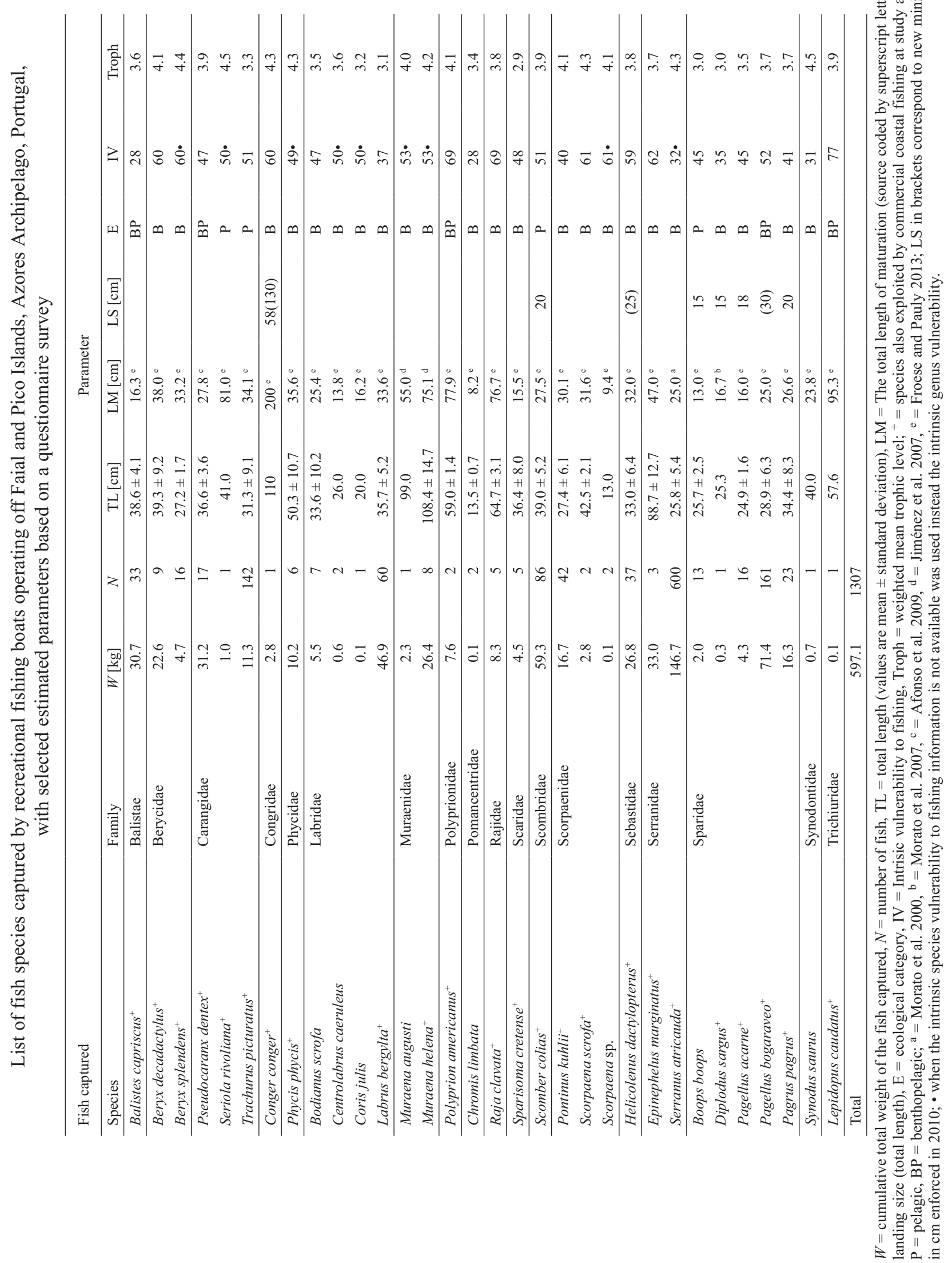


Catch per unit effort (CPUE). The overall CPUE values ranged between 0 and $14.524 \mathrm{~kg}$ per angler per hour and represented an average of $2.305 \pm 2.985 \mathrm{~kg}$ per angler per hour while in number the CPUE ranged between 0 and 44.3 and with an average of 5.0 \pm 7.4 fishes per angler per hour. Angler profile. All interviewed boat anglers were male residents of the island where the survey was carried out and had a mean age of $45.1 \pm 14.0$ years old. Boat owner expenditures averaged $€ 897 \pm € 457$ per year in gear, bait, and all maintenance of the boat, and most expenditure was made almost exclusively in the Azorean region (96.0\%).

Fishing effort and harvest. The majority of the boat anglers interviewed fished all year round (57.4\%) with a mean of $19.6 \pm 13.0$ fishing trips per year and a fishing average of $265 \pm 103$ min per fishing trip (Fig. 4), representing a mean of $86.6 \mathrm{~h}$ per angler per year. The total catch for recreational demersal fishing was calculated for the study area based on total fishing effort in hours, of the recreational fishing fleet, and on the calculated CPUE value (see section 2.4), which reached the $163 \mathrm{t}$.

\section{DISCUSSION}

The most common fishing technique, as determined by the survey in the study area, was demersal fishing and the results obtained indicated potential biological and ecological effects on benthic coastal fish species that cannot be ignored. A considerable number of fish species (32) were sampled in Faial and Pico due in part to the high diversity of benthic species. Anglers using boats captured more species, compared with other recreational activities in the Azorean region, such as spear fishing (27 species, Diogo and Pereira 2013), which is to some extent explained by spear fishing targeting species at inshore areas at depths usually not exceeding $25 \mathrm{~m}$ while boat fishing has a much broader range of fishing depths, catching from subtidal to deepwater species. The catch composition included seven deeper water species: splendid Alfonsino, Beryx splendens; Alfonsino, Beryx decadactylus Cuvier, 1829; offshore rockfish, Pontinus kuhlii; blackbelly rosefish, Helicolenus dactylopterus (Delaroche, 1809); silver scabbardfish, Lepidopus caudatus; wreckfish, Polyprion americanus; and blackspot seabream, Pagellus bogaraveo; that were responsible for $25.1 \%$ of the catch in terms of weight. This result clearly indicates that part of the recreational fleet in Azores fishes down to the $200 \mathrm{~m}$ level, a transition depth zone between the shelf and upper slope assemblages, areas that in Azores are highly accessible to recreational boat fishing since they are close to shore, usually less than 1-1.5 NM (Menezes unpublished*). However the effects of demersal boat fishing in the Azores are clearly more intense on shallow waters and more specifically targets the shallowest fish assemblage, the "islands inner-shelf/hard bottom assemblage" (see Menezes et al. 2006). This assemblage comprises the shore fish community of the Azorean hard bottoms, which are characterized by the highest fish diversity largely due to benthic species (Menezes 2006, Afonso unpublished**). The fact that demersal boat fishing tar-
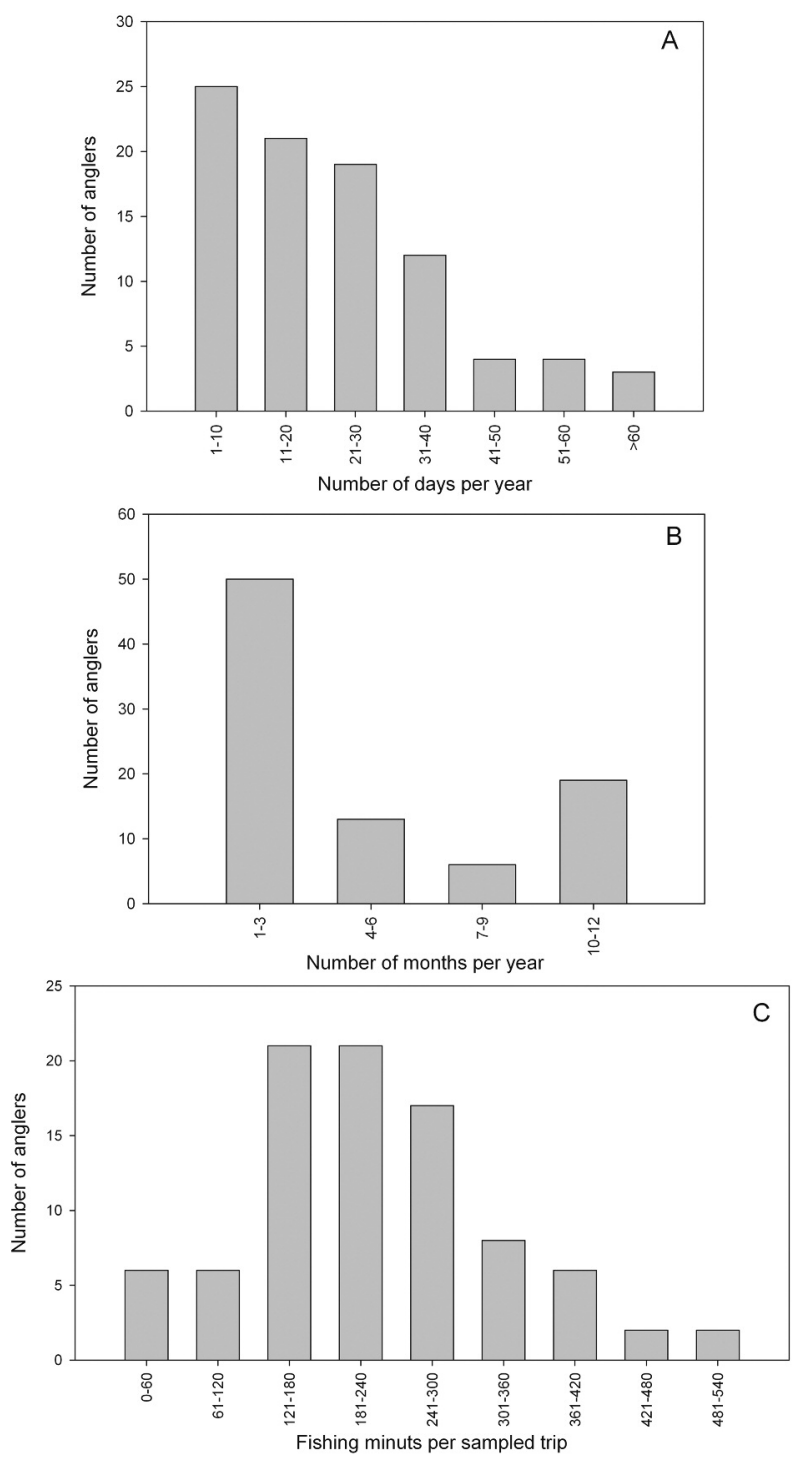

Fig. 4. Fishing effort of the boat-based anglers interviewed during the survey carried out around Faial and Pico islands of the Azores Archipelago, North Atlantic; A number of fishing days per year, B number of months per year, and $\mathbf{C}$ number of fishing minutes per trip sampled

gets a high percentage of fast growing and short-lived species (e.g., blacktail comber, Ballan wrasse) leads to an average intrinsic vulnerability of target species that is considered moderate (45.3 out of 100 ) and also comparatively lower than the mean vulnerability of all worldwide exploited coastal fish species (48 out of 100; Cheung et al. 2007). However, several species with high vulnerability indices were detected in the catches - e.g., silver scabbardfish; wreckfish; dusky grouper, Epinephelus marginatus (Lowe, 1834); and red scorpionfish, Scorpaena scrofa Linnaeus, 1758 - evidencing pressures from demersal fishing on endangered and vulnerable fish species. Three species, barred hogfish, Bodianus scrofa (Valenciennes, 1839); red porgy, Pagrus pagrus (Linnaeus, 1758); and dusky grouper are included on the Red list of IUCN and only dusky

\footnotetext{
${ }^{*}$ Menezes G.M. 2003. Demersal fish assemblages in the Atlantic archipelagos of the Azores, Madeira, and Cape Verde. PhD Dissertation. Departamento Oceanografia e Pescas, Universidade dos Açores, Horta, Azores, Portugal. [In English.]

${ }^{* *}$ Afonso P. 2002. Padrões espaciais na estrutura da comunidade de peixes costeiros dos Açores. [Spatial patterns in the littoral fish community of the Azores.] MSc Thesis. Universidade de Coimbra, Coimbra, Portugal. [In Portuguese.]
} 
grouper is currently protected in Azores, however, only from spear fishing. This study indicated that demersal fishing captures a relatively high volume of fish, which is an indication that this activity has some potential to threaten these endangered species.

Also the analysis of the catch composition gave indications of boat demersal fishing targeting a high range of trophic levels explaining the mean value of 3.8 , which is slightly lower than usually obtained by recreational fishing in other regions, such as the Mediterranean Sea (3.9 for spear fishing, Lloret et al. 2008a; 4.0 for rod-and-reel shore fishing, Font and Lloret 2011). We have to take into account that all of these studies (including this work) based their trophic level estimation on Froese and Pauly (2013). Direct trophic level estimation would certainly have been more accurate, although, in the Azores at least, such studies have not been carried out. Moreover, 8 species (out of 32) were caught with mean lengths below the length at first maturity. Besides being highly threatened in the region by commercial fishing (Pham et al. 2013), recreational boat fishing can add a highly negative effect on the reproductive potential of these species.

In the study area and the studied time period the number of recreational fishing boats was greater than the number of commercial artisanal fishing boats (overall length $<10 \mathrm{~m}$ ) which corresponded to $38.2 \%$ of the recreational fishing fleet (Anonymous 2011b and unpublished data from the Regional Fisheries Inspection; Azorean Government). However, these commercial artisanal boats captured more fishes, since the estimated $163 \mathrm{t}$ per year for recreational demersal boat fishing represented around $39.7 \%$ of landings from commercial artisanal fishing boats (Anonymous 2011b). These results suggest that competition between recreational demersal boat fishing and coastal commercial fishing for marine resources in this area is considerable. Although line fishing from the shore is considered the most popular recreational fishing activity in the region, extracting $\sim 51 \mathrm{t}$ of fish per year (Diogo and Pereira unpublished*), catches correspond to just $28.1 \%$ of the boat fishing catch and $11.6 \%$ of commercial artisanal fishing production; however, the species caught are of low commercial value and overlap little with catches from boat fishing. In opposition the overlapping of captured species between recreational demersal boatbased fishing and commercial artisanal fishing was high since $75 \%$ of the recorded species captured by recreational boat fishing were also captured by commercial fishing. Moreover, several species captured by recreational boat fishing are highly valued commercial species (e.g., blackspot seabream, red porgy, Alfonsino, and wreckfish) representing direct competition for the same resources. In terms of spatial distribution the interviews revealed that recreational vessels tended to operate on a more local scale, which contrasts with commercial artisanal fishermen who are known to frequent not only the slope of the islands but also small offshore fishing grounds around the Azorean Archipelago (da Silva and Pinho 2007). The results presented here clearly pointed to the negative influence of fishing on the communities of demersal fish predators of the shelf and shelf break (0-200 m) with consequences for the commercial artisanal fishermen more dependent on those resources for their livelihoods.

Regardless of whether a fishery is recreational or commercial, it is always of the utmost importance to assess the level of discarding (McPhee et al. 2002). Evidence of discarding in the current study was very low, however, we have to consider that to record the correct level of discards would require the presence of observers onboard. According to Font and Lloret (2011) the reported level of discards recorded at the end of fishing journeys might present incorrect values that in part can be explained by anglers' selective memory. Although the anglers admitted a low level of discards during the interviews, $17.0 \%$ of the anglers declared regularly using part of the catch as bait, which indicated a level of discards certainly higher than the presented values. Another potential indirect negative effect of demersal fishing on the coastal ecosystem is the capture of bait in the intertidal during the low tide. Through the interviews it was determined that half of the captured bait comes from the intertidal zone where the Marbled rock crab species is collected. The impact of this practice on the Azorean intertidal rocky shores comprised of small boulders has yet to be evaluated even though this activity is known to reflect cumulative negative effects, which can be considerable (Underwood 1993).

Azorean recreational boat anglers are mainly middleage males as it happens in several areas of the Mediterranean Sea (Morales-Nin et al. 2005, Pawson et al. 2007, Lloret et al. 2008b). The average expenditure by the owners of recreational fishing boats in fisheries goods and services, is considerably high ( $897 €$ per year) when compared with those reported elsewhere (500€ per year; Lloret et al. 2008b) and the economic activity generated by this specific sector in the study area could ascend to $€ 387000$ per year, extrapolating to the recreational fishing boats licenses of 2008. The economic benefits of this activity have to be taken into account by fisheries managers since over-regulation of the fishery could have negative impacts on the local economy.

The boat anglers interviewed were all local residents and no visiting recreational anglers were encountered during the surveys. In recent years, however, some initiatives have appeared in several islands (e.g., Faial, São Jorge, and São Miguel) offering recreational boat fishing for tourists, a market that has the potential to grow, as occurred some years ago with big game fishing in the region.

During the survey period few specific regulatory measures for recreational boat fishing were in place explaining in part the high level of compliance with the policies enforced. However, in 2009, in order to protect some important commercial fish species, more restricted minimum length values were implemented (see Table 1). To date, this measure must certainly be affecting recreational catch for species such as blackspot seabream since $70.8 \%$ of the fish caught during this study were smaller than the new legal size limits. This species is the most important

\footnotetext{
${ }^{*}$ Diogo H.M.C., Pereira J.G. Biological pressure of recreational inshore fisheries on subtidal fish communities of Azores (Northeast Atlantic). Journal of Fish Biology (submitted).
} 
demersal species targeted by the Azorean commercial handline and bottom longline fisheries, and has been found in recent years to be showing signs of reproductive stress (Stockley et al. 2005) and these new management decisions certainly favour protection of this species. Moreover, $10 \%$ of the recreational boat anglers admitted to selling part of their catch, however given the sensibility of this issue this value is probably underestimated due to incorrect information given by the boat anglers. Commercial fishermen have been systematically exposing this concern to local authorities and, partly in response to these pressures, in 2008 new specific regulations for recreational boat fishing were implemented. Although this legislation was not in force during the study period, we estimated that current bag limits implemented potentially decrease the total catch of demersal fishing by 21.7 percentage points. Moreover, in 2008 new marine protected areas (MPAs) were implemented with four conservation zones in Faial and three in Pico. The combined area of these MPAs within the $200 \mathrm{~m}$ depth margin corresponds to $314 \mathrm{~km}^{2}(42.4 \%$ of total marine area to $200 \mathrm{~m}$ depth). However, recreational boat fishing was only banned in one small zone of $0.1 \mathrm{~km}^{2}$ $(0.03 \%)$ that represents a no take area. As a matter of fact, the only activities highly regulated by management around the MPAs of Faial and Pico are spear fishing and hand collecting of limpets, the remaining commercial and recreational fisheries have been far from consistently regulated in order to reach a good level of protection for vulnerable species and ecosystems.

The outcomes of this study are of extreme importance for coastal fishing management; however further initiatives spanning commercial and recreational sectors should be put in place since their impacts reach beyond leisure or tradition interests. Recreational fishing has important impacts on the economy, on the environment and fish stocks, and when its captures are added to commercial fishing, can magnify the level of ecological impact. Fishery managers should carefully use this information to maximize benefits from commercial and recreational fishing activities. Several results of this study showed the necessity for the continued monitoring of recreational boat fishing in the Azores; the socio-economic importance of this sector needs to be better understood and the impact on fish stocks simultaneously exploited by recreational and commercial fisheries have to be urgently studied for the preservation of Azorean coastal ecosystems.

\section{ACKNOWLEDGMENTS}

The authors wish to thank all the anglers who so kindly collaborated in this study. They are also extremely grateful to Dr Ruth Higgins, Dr Ana Ramos, and Dr Frederic Vandeperre for their valuable help during the project.

\section{REFERENCES}

Afonso P., Fontes J., Holland K.N., Santos R.S. 2009. Multiscale patterns of habitat use in a highly mobile reef fish, the white trevally Pseudocaranx dentex, and their implications for marine reserve design. Marine Ecology Progress Series 381: 273-286. DOI: $10.3354 / \mathrm{meps} 07946$

Anonymous 2011a. Censos 2011. [Census 2011.] Serviços Regionais de Estatística Açorianos, Instituto Nacional de Estatística. [Regional Azorean Statistics Services, National Institute of Statistics] www.srea.ine.pt, version (01/2013) [In Portuguese.]

Anonymous 2011b. Pescado Descarregado na R.A.A. [Fish landed on Azorean Autonomous Region.] Lotaçor S.A. http://www.lotacor.pt/PescadoDescarregadoAuth/gratis.php [In Portuguese.]

Cheung W.W.L., Pitcher T.J., Pauly D. 2005. A fuzzy logic expert system to estimate intrinsic extinction vulnerabilities of marine fishes to fishing. Biological Conservation 124 (1): 97-111. DOI: 10.1016/j.biocon.2005.01.017

Cheung W.W.L., Watson R., Morato T., Pitcher T.J., Pauly D. 2007. Intrinsic vulnerability in the global fish catch. Marine Ecology-Progress Series 333: 1-12. DOI: 10.3354/meps333001

Coleman F.C., Figueira W.F., Ueland J.S., Crowder L.B. 2004. The impact of United States recreational fisheries on marine fish populations. Science 305 (5692): 1958-1960. DOI: $10.1126 /$ science. 1100397

Cooke S.J., Cowx I.G. 2004. The role of recreational fishing in global fish crises. BioScience 54 (9): 857-859. DOI: 10.1641/00063568(2004)054[0857:TRORFI]2.0.CO;2

Cooke S.J., Danylchuk A.J., Danylchuk S.E., Suski C.D., Goldberg T.L. 2006. Is catch-and-release recreational angling compatible with no-take marine protected areas? Ocean and Coastal Management 49 (5-6): 342-354. DOI: 10.1016/j.ocecoaman.2006.03.003

Cowx I.G. 2002. Recreational fishing. Pp. 367-390. In: Hart P., Reynolds J.D. (eds.) Handbook of fish biology and fisheries. Vol. 2. Blackwell Science, Oxford, UK.

da Silva H.M., Pinho M.R. 2007. Small-scale fishing on seamounts. Chapter 16. Pp. 334-360. In: Pitcher T.J., Morato T., Hart P.J.B., Clark M.R., Haggan N., Santos R.S. (eds.) Seamounts: ecology, fisheries and conservation. Fish and Aquatic Resources Series. Vol. 12. Blackwell, Oxford, UK.

Diogo H.M.C., Pereira J.G. 2013. Impact evaluation of spear fishing on fish communities in an urban area of São Miguel Island (Azores Archipelago). Fisheries Management and Ecology 20 (6): 473-483. DOI: 10.1111/fme.12036

Font T., Lloret J. 2011. Biological implications of recreational shore angling and harvest in a marine reserve: the case of Cape Creus. Aquatic conservation: Marine and Freshwater Ecosystems 21 (2): 210-217. DOI: 10.1002/aqc.1167

Froese R., Pauly D. (eds.) 2013. FishBase. [version 01/2013] http://www.fishbase.org

Guénette S., Morato T. 2001. The Azores Archipelago, 1997. Pp. 241-270 In: Guénette S., Christensen V., Pauly D. (eds.). Fisheries impacts on North Atlantic ecosystems: Models and analyses. Fisheries Centre Research Reports Vol. 9 (4). University of British Colombia. Vancouver, BC, Canada.

Jiménez S., Schönhuth S., Lozano I.J., González J.A., Sevilla R.G., Diez A., Bautista J.M. 2007. Morphological, ecological, and molecular analyses separate Muraena augusti from Muraena helena as a valid species. Copeia 2007 (1): 101-113 DOI: 10.1643/0045-8511(2007)7[101:MEAMAS]2.0.CO;2 
Lloret J., Zaragoza N., Caballero D., Font T., Casadevall M., Riera V. 2008a. Spearfishing pressure on fish communities in rocky coastal habitats in a Mediterranean marine protected area. Fisheries Research 94 (1): 84-91. DOI: 10.1016/j.fishres.2008.07.002

Lloret J., Zaragoza N., Caballero D., Riera V. 2008b. Biological and socioeconomic implications of recreational boat fishing for the management of fishery resources in the marine reserve of Cap de Creus (NW Mediterranean). Fisheries Research 91 (2-3): 252-259. DOI: 10.1016/ j.fishres.2007.12.002

Marta P., Bochechas J., Collares-Pereira M.J. 2001. Importance of recreational fisheries in the Guadiana River basin in Portugal. Fisheries Management and Ecology 8 (4-5): 345-354. DOI: 10.1111/j.1365-2400.2001.00262.x

McGlennon D., Kinloch M.A. 1997. Evaluation of the busroute creel survey method in a large Australian marine recreational fishery II. Pilot surveys and optimal sampling allocation. Fisheries Research 33 (1-3): 89-99. DOI: 10.1016/ S0165-7836(97)00067-2

McPhee D.P., Leadbitter D., Skilleter G.A. 2002. Swallowing the bait: is recreational fishing in Australia ecologically sustainable? Pacific Conservation Biology 8: 40-51.

Menezes G.M., Sigler F.G., Silva H.M., Pinho M.R. 2006. Structure and zonation of demersal fish assemblages off the Azores Archipelago (mid-Atlantic). Marine Ecology Progress Series 324: 241-260. DOI: 10.3354/meps324241

Morales-Nin B., Moranta J., García C., Tugores M.P., Grau A.M., Riera F., Cerdà M. 2005. The recreational fishery off Majorca Island (western Mediterranean): some implications for coastal resource management. ICES Journal of Marine Science 62 (4): 727-739. DOI: 10.1016/j.icesjms. 2005.01.022

Morato T., Santos R.S., Andrade J.P. 2000. Feeding habits, seasonal and ontogenetic diet shift of blacktail comber, Serranus atricauda (Pisces: Serranidae), from the Azores, north-eastern Atlantic. Fisheries Research 49 (1): 51-59. DOI: $10.1016 / \mathrm{S} 0165-7836(00) 00189-2$

Morato T., Afonso P., Lourinho P., Barreiros J.P., Santos R.S., Nash R.D.M. 2001. Length-weight relationships for 21 coastal fish species of the Azores, north-eastern Atlantic. Fisheries Research 50 (3): 297-302. DOI: 10.1016/S01657836(00)00215-0

Morato T., Afonso P., Lourinho P., Nash R.D.M., Santos R.S. 2003. Reproductive biology and recruitment of the white sea bream in the Azores. Journal of Fish Biology 63 (1): 59-72. DOI: $10.1046 / j .1095-8649.2003 .00129 . x$ [Not cited in the text]

Pauly D., Christensen V. 2000. Trophic levels of fishes. In: Froese R., Pauly D. (eds). FishBase 2000: Concepts, design and data sources. ICLARM, Manila, Philippines.
Pawson M.G., Tingley D., Padda G., Glenn H. 2007. EU contract FISH/2004/011 on "Sport fisheries" (or marine recreational fisheries) in the EU. Final report, CEFAS-European Commission Directorate-General for Fisheries, Lowestoft. http://www.cefas.co.uk/publications/files/sportsfishingc2362.pdf

Pham C.K., Canha A., Diogo H., Pereira J.G., Prieto R., Morato T. 2013. Total marine fishery catch for the Azores (1950-2010). ICES Journal of Marine Science 70 (3): 564-577. DOI: 10.1093/icesjms/fst024

Pitcher T.J., Hollingworth C.E. 2002. Recreational fisheries: Ecological, economic and social evaluation. Fish and Aquatic Resources Series 8, Blackwell Science, Oxford, UK.

Pollock K.H., Jones C.M., Brown T.L. 1994. Angler survey methods and their applications in fisheries management. American Fisheries Society Special Publication 25.

Quartau R., Trenhail A.S., Mitchell N.C., Tempera F. 2010. Development of volcanic insular shelves: Insights from observation and modeling of Faial in the Azores Archipelago. Marine Geology 275: 66-83. DOI: 10.1016/ j.margeo.2010.04.008

Sigler W.F., Sigler J.W. 1990. Recreational fisheries. Management, theory, and application. University of Nevada Press, Las Vegas, NV, USA.

Southard J.B., Stanley D.J. 1976. Shelf-break processes and sedimentation. Pp. 351-377. In: Stanley D.J., Swift D.J.P. (eds.), Marine Sediment Transport and Environmental Management. John Wiley and Sons, New York, USA.

Stockley B., Menezes G., Pinho M.R., Rogers A.D. 2005. Genetic population structure in the black-spot sea bream (Pagellus bogaraveo Brünnich, 1768) from the NE Atlantic. Marine Biology 146 (4): 793-804. DOI: 10.1007/s00227004-1479-3

Underwood A.J. 1993. Exploitation of species on the rocky coast of New South Wales (Australia) and options for its management. Ocean and Coastal Management 20 (1): 41-62. DOI: 10.1016/0964-5691(93)90012-N

Wise B.S., Telfer C.F., Lai E.K.M., Hall N.G., Jackson G. 2012. Long-term monitoring of boat-based recreational fishing in Shark Bay, Western Australia: providing scientific advice for sustainable management in a World Heritage Area. Marine and Freshwater Research 63 (11): 1129-1141. DOI: $10.1071 / \mathrm{MF} 12054$

Received: 8 March 2013 Accepted: 30 October 2013 Published electronically: 31 December 2013 